\title{
ANALISIS PENAMPANG KOLOM BETON BERTULANG PERSEGI PANJANG BERLUBANG
}

\author{
Marzon $^{1)}$, Mukhlis Islam ${ }^{2)}$, Elhusna $^{3)}$ \\ ${ }^{12) 33}$ Program Studi Teknik Sipil, Fakultas Teknik UNIB, Jl. W. R. Supratman, \\ Kandang Limun, Bengkulu 38371, Telp. (0736)344087 \\ email: Inersia@unib.ac.id
}

\begin{abstract}
Abstrak
Pemasangan pipa pada kolom bangunan (conduit) banyak ditemukan dalam struktur beton bertulang. Pemasangan pipa di dalam kolom dimanfaatkan sebagai saluran pipa sanitasi dan mekanikal/elektrikal. Studi kasus dalam penelitian ini ialah menganalisis kolom persegi panjang berlubang dengan jenis penelitian terapan (applied/pratical research). Penelitian ini bertujuan untuk mengetahui seberapa pengaruh lubang terhadap kolom persegi panjang berlubang sentris. Perhitungan ini terdiri dari 675 sampel dengan berbeda mutu beton $\left(f^{\prime} c\right)$, luas tulangan, luas lubang, dan dimensi kolom. Analisis perhitungan kolom persegi panjang berlubang menggunakan hubungan diagram tegangan-regangan Hognestad. Hasil analisis terhadap kolom persegi panjang berlubang mengakibatkan penurunan kapasitas kolom. Penurunan kapasitas kolom persegi panjang terbesar terjadi pada luas lubang $7 \%$, mutu beton $30 \mathrm{MPa}$, dan dimensi kolom 450 x $1800 \mathrm{~mm}$ adalah 16,97\%.
\end{abstract}

Kata kunci: kolom beton bertulang, kolom berlubang, hubungan tegangan regangan hognestad, rasio tulangan, kapasitas kolom

\begin{abstract}
Abstrak
Installation of pipes (conduit) in the building columns often found in reinforced concrete structures. The installation of pipes inside the columns is utilized as sanitary and mechanical electrical pipes. The case research in this study is to analyze the rectangular column with the applied research type (applied/pratical research). This research aims to analyze the impact of the holes on square rectangular columns. This calculation consists of 675 samples with different concrete compression strength $\left(f^{\prime} c\right)$, reinforcement area, holes area, and the dimensions of the column. Analysis of the calculation of hollow rectangular columns using the stress-strain relationship equation developed by Hognestaad. The results of the analysis on hollow rectangular columns resulted in a decrease column capacity. The largest decrease of the rectangular column capacity occurred on holes area of 7\%, with concrete compression strength $30 \mathrm{MPa}$, and dimensions of the column $450 \times 1800 \mathrm{~mm}$ which is $16.97 \%$.
\end{abstract}

Keyword: reinforced concrete column, hollow column, stress-strain hognestaads relation, ratio of reinforcement, column capacity. 


\section{PENDAHULUAN}

Perencanaan sebuah bangunan bertujuan mendapatkan elemen struktur yang dapat menyokong bentuk arsitekturnya dengan jaminan mutu bangunan yang baik. struktur yang baik memberikan kenyamanan dan keamanan bagi penghuninya.

Elemen struktur yang baik harus didesain dengan analisis struktur yang memadai. Analisis struktur dilakukan untuk mengetahui besarnya gaya-gaya dalam dari suatu elemen struktur bangunan. Perhitungan gaya dalam tersebut digunakan untuk mendesain dimensi sampai dengan jumlah tulangan dari struktur beton bertulang yang digunakan. Proses ini memerlukan perhitungan yang berulang (trial error) untuk mendapatkan hasil dari suatu elemen struktur yang kuat dan ekonomis. Proses ini juga mencakup komponen tekan biasa disebut dengan kolom.

\section{Kolom}

Kolom merupakan komponen struktur bangunan yang tugas utamanya menyangga beban aksial tekan vertikal $(\mathrm{Pn})$ dan momen nominal (Mn) pada sebuah bangunan. Kolom menempati peranan penting di dalam sistem struktur bangunan. Kegagalan kolom berakibat langsung pada runtuhnya komponen struktur lain yang berhubungan dengannya (Nawy, 2010).

Kolom sering digunakan sebagai tempat penyaluran pipa-pipa drainase ataupun instalasi mekanikal elektrikal dan sebagainya. Pemasangan pipa ini dapat menyebabkan berkurangnya luas penampang kolom. Pengurangan tersebut dapat berakibat mengurangi kapasitas kekuatan dari kolom tersebut.

Pasal 6.3.4 SNI-2847-2013 telah membatasi luasan lubang maksimal sebesar $4 \%$ dari luas penampang kolom untuk perkuatan dan perlindungan terhadap kebakaran. Penelitian yang pernah dilakukan Renjani (2011) menunjukan penurunan kapasitas gaya aksial kolom $\left(\mathrm{P}_{\mathrm{n}}\right)$ sebesar $10,42 \%$ terjadi pada luas lubang $7 \%$ dari luas penampang kolom yang terletak ditengah titik berat penampang maka besarnya lubang harus diperhitungkan terhadap pengaruh kekuatanya. Artikel ini membahas pengaruh lubang dalam kolom beton bertulang untuk kolom berpenampang persegi panjang terhadap kekuatannya dalam memikul beban.

\section{METODE PENELITIAN}

Analisis kolom persegi panjang berlubang ini dikembangkan menggunakan aplikasi spreadsheet. Penjelasan tahapan analisis kolom beton bertulang berpenampang persegi panjang dengan tulangan longitudinal dua muka adalah sebagai berikut:

1. Elemen struktur beton bertulang yang hanya mengalami kombinasi momen lentur uniaksial.

2. Rasio tulangan longitudinal pada kolom berpenampang persegi panjang dengan menggunakan hubungan antara teganganregangan Hognestad.

3. Menggunakan aplikasi spreadsheet.

4. Batasan parameter-parameter perhitungan antara lain :

a. Mutu beton $\left(f_{\mathrm{c}}{ }^{\prime}\right)$ yang diambil adalah mutu beton yang sering dipakai yaitu (25-30) MPa dengan kenaikan (increment) 2,5 $\mathrm{MPa}$.

b. Luas tulangan (1-5)\% dari luas penampang kolom dengan kenaikan (increment) 2\% (berdasarkan SNI2847-2013 pasal 10.9.1 dengan luas tulangan (1-8)\%).

c. Dimensi kolom persegi panjang lebar (25-45) $\mathrm{cm}$ dengan kenaikan (increment) $5 \mathrm{~cm}$ dan panjang (100300) \% kali lebar kolom dengan kenaikan (increment) 100\%. 
d. Mutu tulangan $\left(\mathrm{f}_{\mathrm{y}}\right)$ adalah $400 \mathrm{MPa}$.

e. Luas lubang (3-7)\% dengan kenaikan (increment) $1 \% \quad$ (berdasarkan SNI-2847-2013 Pasal 6.3.4 dengan luas lubang maksimum 4\%).

5. Teori regangan beton yang dipakai ialah teori tegangan-regangan Hognestad dengan nilai $\varepsilon_{\mathrm{cu}}=0,0038 \mathrm{~mm}$.

6. Modulus Elastisitas baja (Es) sebesar 200.000 MPa.

\section{HASIL DAN PEMBAHASAN}

\section{Analisis grafik interaksi Pn-Mn}

Perencanaan kolom yang dilaporkan pada sebuah proyek pembangunan salah satu gedung di Kota Bengkulu dengan mutu beton (f'c) $25 \mathrm{MPa}$ yang berdimensi kolom persegi panjang $250 \times 500 \mathrm{~mm}$. Mutu baja tulangan (fy) pada proyek tersebut sebesar $400 \mathrm{MPa}$. Salah satu kolom persegi panjang akan dimasukan pipa sanitasi dengan luas lubang sanitasi $3 \%$ dari luas penampang kolom dan luas tulangan $1 \%$.

Data analisis ini menggunakan beberapa asumsi-asumsi dasar yang biasa digunakan dalam perhitungan struktur kolom. Penggunaan metode iterasi dilakukan berulang untuk mendapatkan grafik pada titik-titik tertentu. Jarak antara garis netral dengan tepi serat beton tekan $\mathrm{C}$ diasumsikan sebanyak 20 buah untuk satu nilai $\mathrm{C}$ dibagi menjadi 100 segmen.

Perhitungan akan berhenti ketika telah mencapi 100 segmen dengan satu nilai C menghasilkan satu gaya aksial dan momen nominal. Titik-titik dari masing-masing nilai $\mathrm{C}$ digabungkan sehingga menjadi grafik interaksi gaya aksial (Pn) dan momen nominal (Mn). Hasil perhitungan untuk setiap asumsi nilai $\mathrm{C}$ semuanya dilampirkan.

Asumsi-asumsi nilai $\mathrm{C}$ yang digunakan penulis dalam perhitungan untuk data perencanaan kolom persegi panjang berlubang 3\% dapat dilihat pada Tabel 1 dan Tabel 2.

Tabel 1. Tabel Asumsi Nilai C

\begin{tabular}{|c|c|c|c|}
\hline $\begin{array}{c}\text { Asumsi } \\
\mathrm{C}\end{array}$ & $\mathrm{mm}$ & $\begin{array}{c}\text { Asumsi } \\
\mathrm{C}\end{array}$ & $\mathrm{Mm}$ \\
\hline 1 & 500 & 11 & 265,45 \\
\hline 2 & 476,48 & 12 & 242,62 \\
\hline 3 & 452,95 & 13 & 219,79 \\
\hline 4 & 429,43 & 14 & 196,97 \\
\hline 5 & 405,90 & 15 & 174,14 \\
\hline 6 & 382,38 & 16 & 151,31 \\
\hline 7 & 358,85 & 17 & 128,48 \\
\hline 8 & 335,33 & 18 & 105,66 \\
\hline 9 & 311,80 & 19 & 82,83 \\
\hline 10 & 288,28 & 20 & 56,95 \\
\hline
\end{tabular}

Nilai C untuk setiap asumsi diatas kemudian dilakukan analisis perhitungan untuk mendapatkan nilai gaya aksial $(\mathrm{Pn})$ dan momen nominal (Mn). Hasil analisis perhitungan untuk setiap nilai $\mathrm{C}$ dapat dilihat pada Tabel 2 .

Data tersebut digunakan untuk mendapatkan grafik interaksi gaya aksial (Pn) dan momen nominal (Mn) pada mutu beton (f'c) 25 MPa, dimensi 250 × $500 \mathrm{~mm}$ mutu baja tulangan (fy) $400 \mathrm{MPa}$ dan luas tulangan $1 \%$. Grafik interaksi gaya aksial (Pn) dan momen nominal $(\mathrm{Mn})$ tersebut dapat dilihat pada Gambar 1. 
Tabel 2. Tabel Nilai Pn dan Mn untuk Masing-Masing Nilai C

\begin{tabular}{|c|c|c|c|c|c|}
\hline \multirow{2}{*}{$\begin{array}{c}\text { Asumsi C } \\
(\mathrm{mm})\end{array}$} & \multicolumn{2}{|c|}{$\begin{array}{c}\text { Kolom persegi panjang } \\
\text { berlubang }\end{array}$} & \multirow{2}{*}{$\begin{array}{c}\text { Asumsi C } \\
(\mathrm{mm})\end{array}$} & \multicolumn{2}{c|}{$\begin{array}{c}\text { Kolom persegi panjang tidak } \\
\text { berlubang }\end{array}$} \\
\cline { 6 - 6 } & Pn $(\mathrm{kN})$ & Mn $(\mathrm{kN} . \mathrm{m})$ & & Pn $(\mathrm{kN})$ & Mn $(\mathrm{kN} . \mathrm{m})$ \\
\hline Aksial & 3050 & 0 & Aksial & 3130 & 0 \\
\hline 500 & 2632,988 & 108,284 & 500 & 2724,733 & 108,518 \\
\hline 476,48 & 2498,179 & 132,705 & 476,48 & 2590,341 & 132,938 \\
\hline 452,95 & 2362,349 & 155,145 & 452,95 & 2453,806 & 155,407 \\
\hline 429,43 & 2225,209 & 175,774 & 429,43 & 2314,774 & 175,992 \\
\hline 405,90 & 2086,427 & 194,554 & 405,90 & 2172,813 & 194,776 \\
\hline 382,38 & 1944,481 & 211,618 & 382,38 & 2027,380 & 211,862 \\
\hline 358,85 & 1801,195 & 227,141 & 358,85 & 1877,794 & 227,379 \\
\hline 335,33 & 1654,662 & 241,216 & 335,33 & 1723,181 & 241,493 \\
\hline 311,80 & 1505,207 & 254,134 & 311,80 & 1562,402 & 254,421 \\
\hline 288,28 & 1352,356 & 266,112 & 288,28 & 1393,948 & 266,449 \\
\hline 265,45 & 1261,867 & 265,460 & 265,45 & 1283,566 & 265,781 \\
\hline 242,62 & 1166,811 & 262,741 & 242,62 & 1173,184 & 262,894 \\
\hline 219,79 & 1062,693 & 257,782 & 219,79 & 1062,802 & 257,785 \\
\hline 196,97 & 952,420 & 250,457 & 196,97 & 952,420 & 250,457 \\
\hline 174,14 & 842,038 & 240,909 & 174,14 & 842,038 & 240,909 \\
\hline 151,31 & 731,656 & 229,140 & 151,31 & 731,656 & 229,140 \\
\hline 128,48 & 621,274 & 215,151 & 128,48 & 621,274 & 215,151 \\
\hline 105,66 & 466,146 & 190,440 & 105,66 & 466,146 & 190,440 \\
\hline 82,83 & 281,421 & 157,885 & 82,83 & 281,421 & 157,885 \\
\hline 56,95 & 0 & 104,613 & 56,95 & 0 & 104,613 \\
\hline & & & & & \\
\hline
\end{tabular}

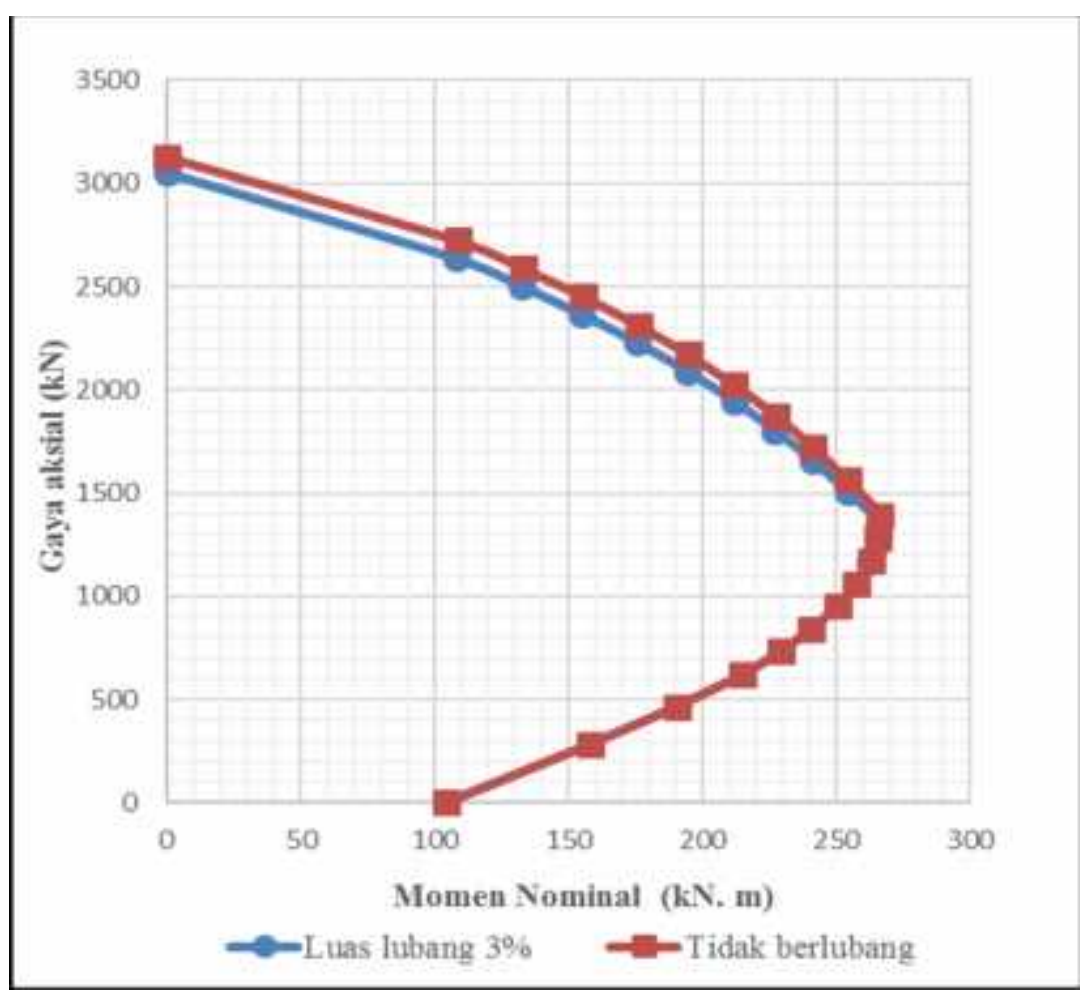

Gambar 1. Grafik Interaksi Pn dan Mn Kolom Persegi Panjang Hasil Analisis 
Analisis grafik persentase selisih gaya aksial (Pn)

dimensi kolom $250 \times 500 \mathrm{~mm}$, mutu beton Grafik persentase selisih gaya aksial $25 \mathrm{MPa}$, mutu baja $400 \mathrm{MPa}$, luas tulangan terhadap besaran eksentrisitas dengan $1 \%, 3 \%$, dan 5\% dapat dilihat pada Gambar 2 sebagai berikut:

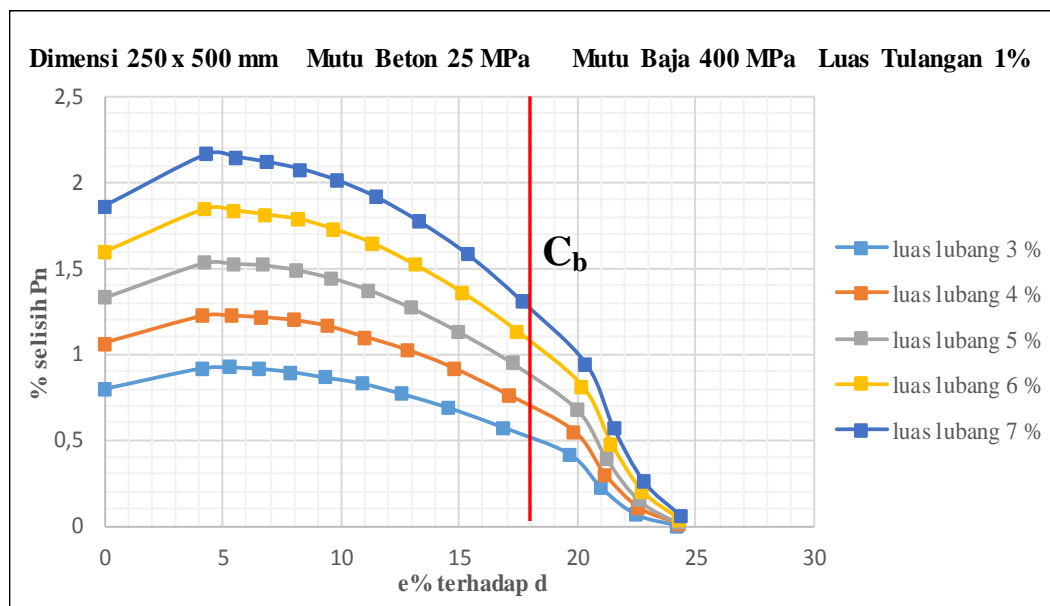

a. Luas tulangan $1 \%$

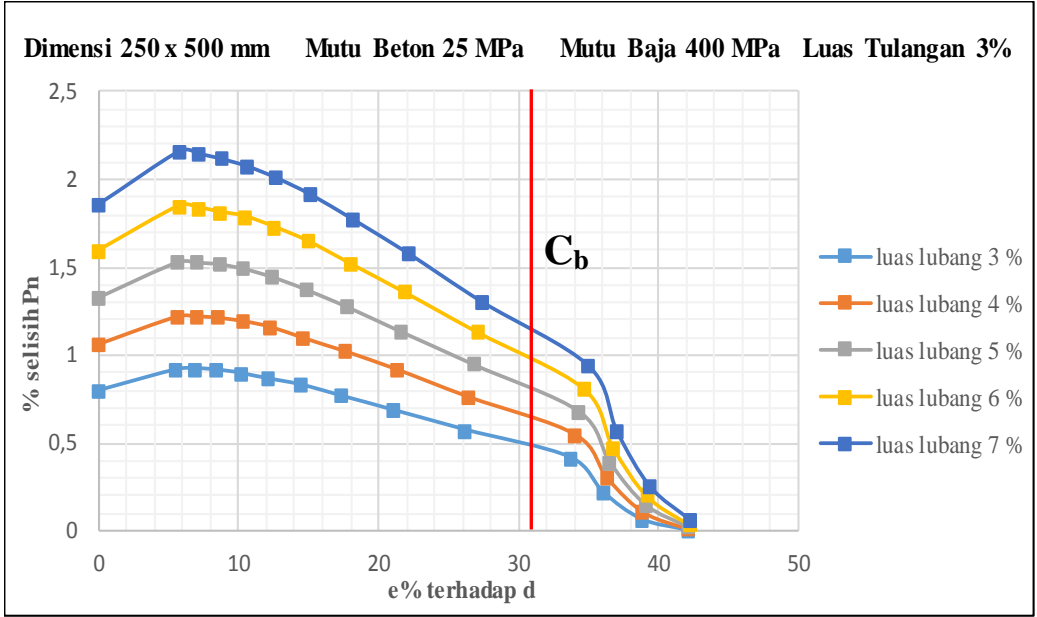

b. Luas tulangan $3 \%$

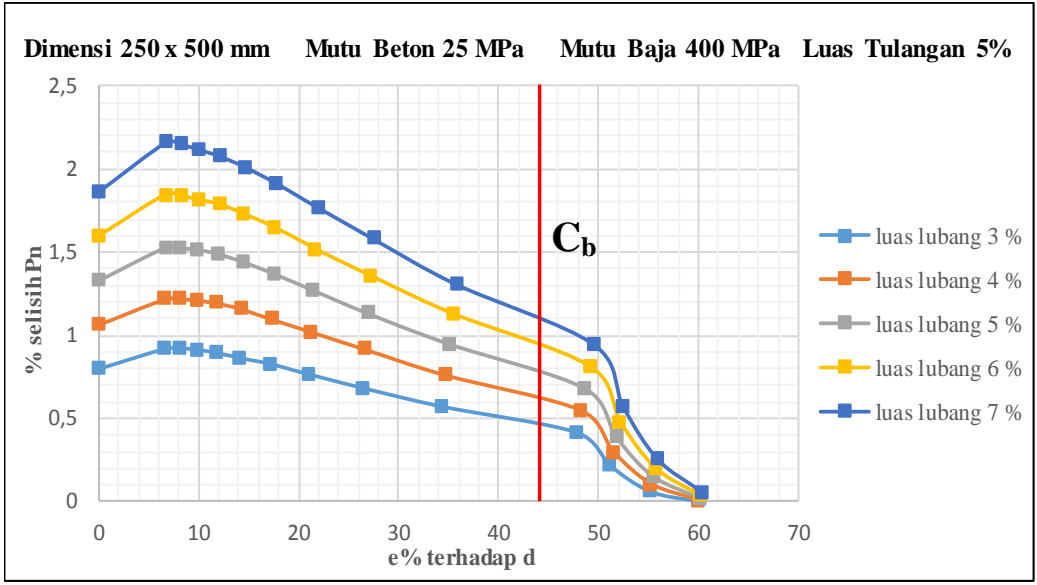

c. Luas tulangan $5 \%$

Gambar 1. Grafik Persentase Selisih Pn terhadap Eksentrisitas 
Analisis grafik persentase selisih momen nominal (Mn)

Grafik persentase selisih momen nominal terhadap besaran eksentrisitas dengan dimensi kolom 250 x $500 \mathrm{~mm}$, mutu beton $25 \mathrm{MPa}$, mutu baja $400 \mathrm{MPa}$, luas tulangan $1 \%, 3 \%$, dan $5 \%$ dapat dilihat pada Gambar 4.4 sebagai berikut:

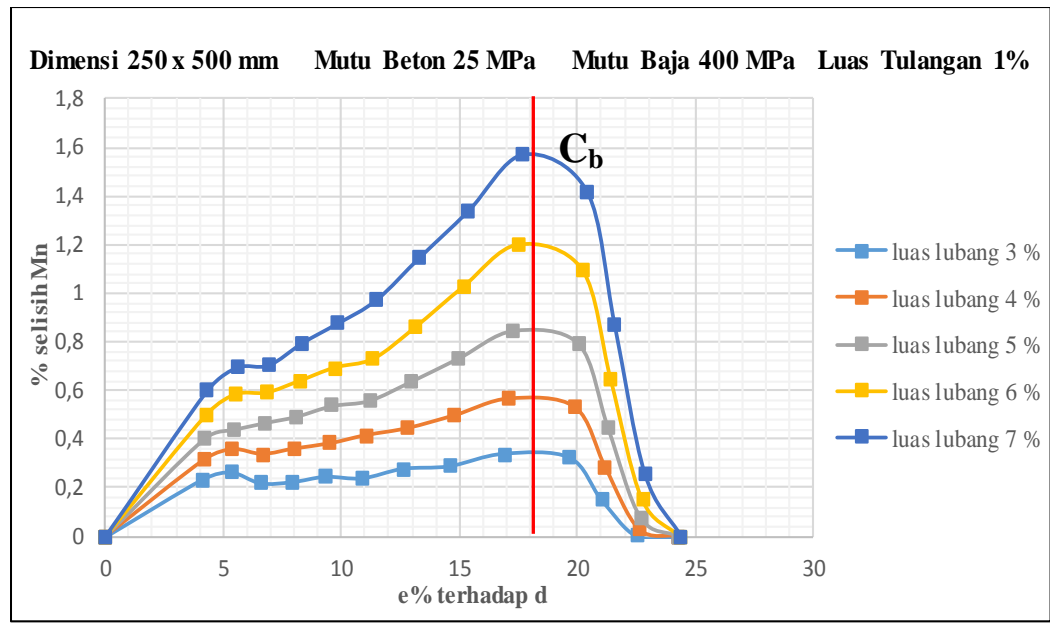

a. Luas tulangan $1 \%$

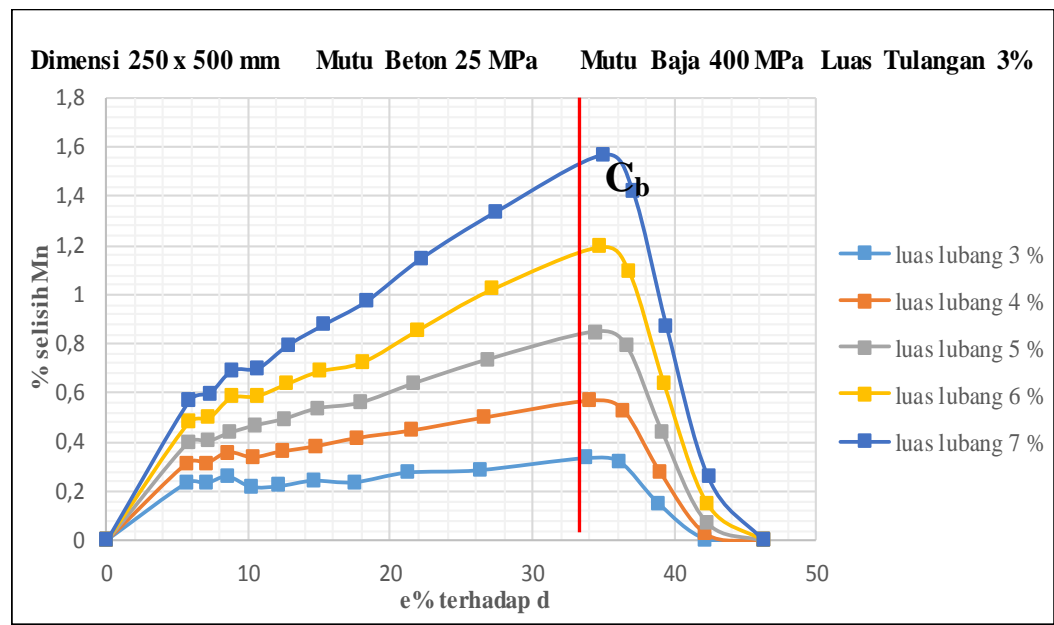

a. Luas tulangan $3 \%$

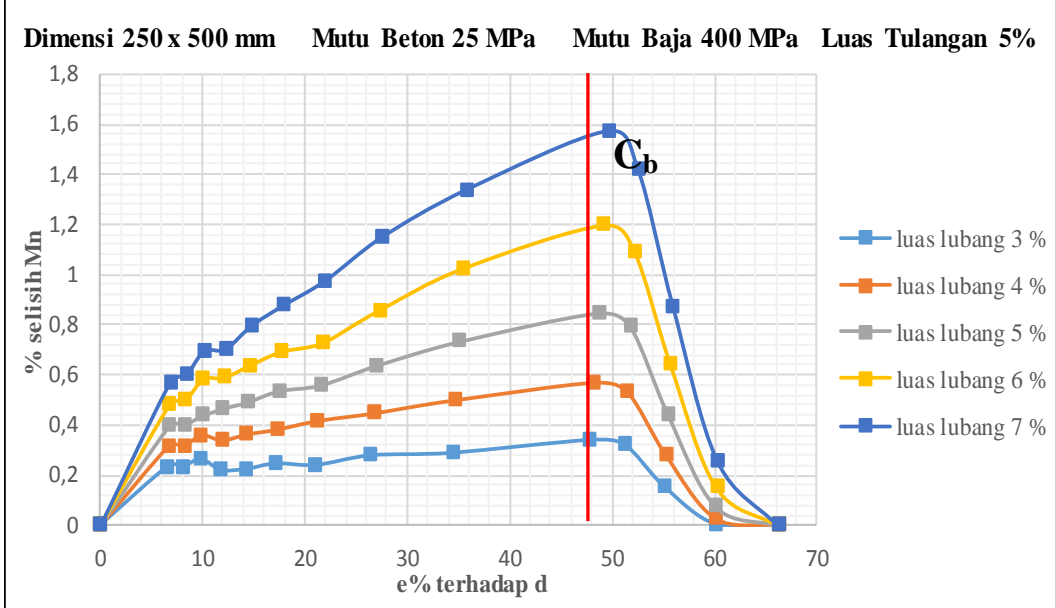

b. Luas tulangan $5 \%$

Gambar 2. Grafik Persentase Selisih Mn terhadap Eksentrisitas 
Perbandingan hasil penelitian dengan hasil penelitian Renjani, 2011

Hasil penelitian (Tabel 3) tentang analisis kolom beton bertulang pada penampang persegi panjang berlubang dibandingkan dengan penelitian sebelumnya (Tabel 4) tentang analisis penampang kolom beton bertulang persegi berlubang (Renjani, 2011).

Tabel 3. Hasil Penelitian

\begin{tabular}{|c|c|c|c|c|c|c|c|c|}
\hline \multirow{2}{*}{ No } & \multicolumn{2}{|c|}{ Dimensi $(\mathrm{mm})$} & \multirow{2}{*}{$\begin{array}{c}\mathrm{A}_{\mathrm{g}} \\
\left(\mathrm{m}^{2}\right)\end{array}$} & \multirow{2}{*}{$\begin{array}{c}\text { f'c } \\
(\mathrm{MPa})\end{array}$} & \multirow{2}{*}{$\begin{array}{c}\text { Selisih Pn } \\
\text { Max }\end{array}$} & \multirow{2}{*}{$\begin{array}{c}\text { e Terhadap } \\
\mathrm{d}\end{array}$} & \multirow{2}{*}{$\begin{array}{c}\text { Selisih } \\
\text { Mn Max }\end{array}$} & \multirow{2}{*}{$\begin{array}{c}\text { e Terhadap } \\
\text { d }\end{array}$} \\
\hline & $\mathrm{b}$ & $\mathrm{h}$ & & & & & & \\
\hline \multirow{3}{*}{1.} & \multirow{3}{*}{250} & \multirow{3}{*}{500} & \multirow{3}{*}{0,13} & 25 & $2,16 \%$ & $4,30 \%$ & $1,57 \%$ & $17,68 \%$ \\
\hline & & & & 27,5 & $2,38 \%$ & $4,22 \%$ & $1,73 \%$ & $17,20 \%$ \\
\hline & & & & 30 & $2,59 \%$ & $4,14 \%$ & $1,88 \%$ & $16,80 \%$ \\
\hline \multirow{3}{*}{2.} & \multirow{3}{*}{300} & \multirow{3}{*}{600} & \multirow{3}{*}{0,18} & 25 & $3,11 \%$ & $5,37 \%$ & $2,67 \%$ & $21,30 \%$ \\
\hline & & & & 27,5 & $3,42 \%$ & $5,25 \%$ & $2,91 \%$ & $20,69 \%$ \\
\hline & & & & 30 & $3,74 \%$ & $5,15 \%$ & $3,17 \%$ & $20,18 \%$ \\
\hline \multirow{3}{*}{3.} & \multirow{3}{*}{350} & \multirow{3}{*}{700} & \multirow{3}{*}{0,25} & 25 & $4,24 \%$ & $6,44 \%$ & $4,14 \%$ & $28,62 \%$ \\
\hline & & & & 27,5 & $4,66 \%$ & $6,28 \%$ & $4,56 \%$ & $27,64 \%$ \\
\hline & & & & 30 & $5,08 \%$ & $6,15 \%$ & $4,97 \%$ & $26,81 \%$ \\
\hline \multirow{3}{*}{4.} & \multirow{3}{*}{300} & \multirow{3}{*}{1200} & \multirow{3}{*}{0,36} & 25 & $6,29 \%$ & $11,86 \%$ & $6,25 \%$ & $49,26 \%$ \\
\hline & & & & 27,5 & $6,92 \%$ & $11,52 \%$ & $6,87 \%$ & $47,47 \%$ \\
\hline & & & & 30 & $7,54 \%$ & $11,24 \%$ & $7,49 \%$ & $45,98 \%$ \\
\hline
\end{tabular}

Tabel 4. Hasil Penelitian Renjani (2011)

\begin{tabular}{|c|c|c|c|c|c|c|c|c|}
\hline \multirow{2}{*}{ No } & \multicolumn{2}{|c|}{ Dimensi $(\mathrm{mm})$} & \multirow{2}{*}{$\underset{\left(\mathrm{m}^{2}\right)}{\mathrm{A}_{\mathrm{g}}}$} & \multirow{2}{*}{$\begin{array}{c}\mathrm{f}^{\prime} \mathrm{c} \\
(\mathrm{MPa})\end{array}$} & \multirow{2}{*}{$\begin{array}{l}\text { Selisih } \\
\text { Pn Max }\end{array}$} & \multirow{2}{*}{$\begin{array}{c}\text { e Terhadap } \\
\text { d }\end{array}$} & \multirow{2}{*}{$\begin{array}{c}\text { Selisih } \\
\text { Mn Max }\end{array}$} & \multirow{2}{*}{$\begin{array}{c}\text { e Terhadap } \\
\text { d }\end{array}$} \\
\hline & $\mathrm{b}$ & $\mathrm{h}$ & & & & & & \\
\hline \multirow{3}{*}{1.} & \multirow{3}{*}{300} & \multirow{3}{*}{300} & \multirow{3}{*}{0,09} & 25 & $6,74 \%$ & $33,95 \%$ & $0,59 \%$ & $73,29 \%$ \\
\hline & & & & 27,5 & $6,99 \%$ & $33,41 \%$ & $0,63 \%$ & $46,68 \%$ \\
\hline & & & & 30 & $7,22 \%$ & $32,92 \%$ & $0,66 \%$ & $45,65 \%$ \\
\hline \multirow{3}{*}{2.} & \multirow{3}{*}{400} & \multirow{3}{*}{400} & \multirow{3}{*}{0,16} & 25 & $7,32 \%$ & $52,00 \%$ & $0,52 \%$ & $24,46 \%$ \\
\hline & & & & 27,5 & $7,53 \%$ & $50,35 \%$ & $0,55 \%$ & $68,34 \%$ \\
\hline & & & & 30 & $7,72 \%$ & $48,89 \%$ & $0,59 \%$ & $65,70 \%$ \\
\hline \multirow{3}{*}{3.} & \multirow{3}{*}{500} & \multirow{3}{*}{500} & \multirow{3}{*}{0,25} & 25 & $7,70 \%$ & $70,11 \%$ & $0,47 \%$ & $95,13 \%$ \\
\hline & & & & 27,5 & $7,86 \%$ & $67,01 \%$ & $0,50 \%$ & $89,66 \%$ \\
\hline & & & & 30 & $8,04 \%$ & $50,80 \%$ & $0,54 \%$ & $85,03 \%$ \\
\hline \multirow{3}{*}{4.} & \multirow{3}{*}{600} & \multirow{3}{*}{600} & \multirow{3}{*}{0,36} & 25 & $8,03 \%$ & $69,20 \%$ & $0,45 \%$ & $28,19 \%$ \\
\hline & & & & 27,5 & $8,20 \%$ & $66,06 \%$ & $0,48 \%$ & $83,29 \%$ \\
\hline & & & & 30 & $9,82 \%$ & $98,99 \%$ & $0,50 \%$ & $26,73 \%$ \\
\hline
\end{tabular}

Sumber : Renjani, 2011 


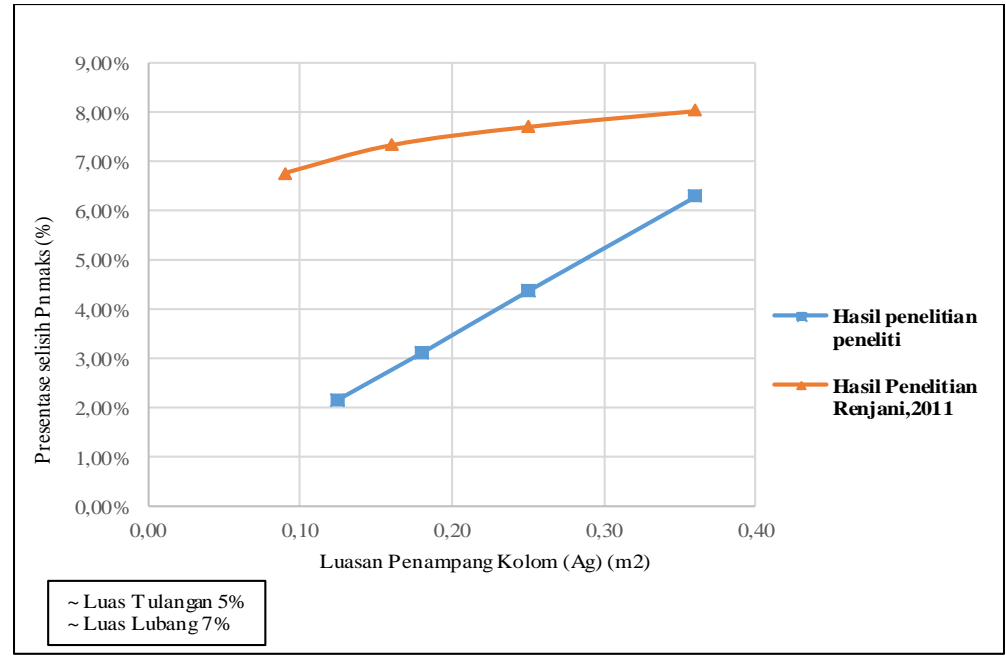

a. Mutu beton $25 \mathrm{MPa}$

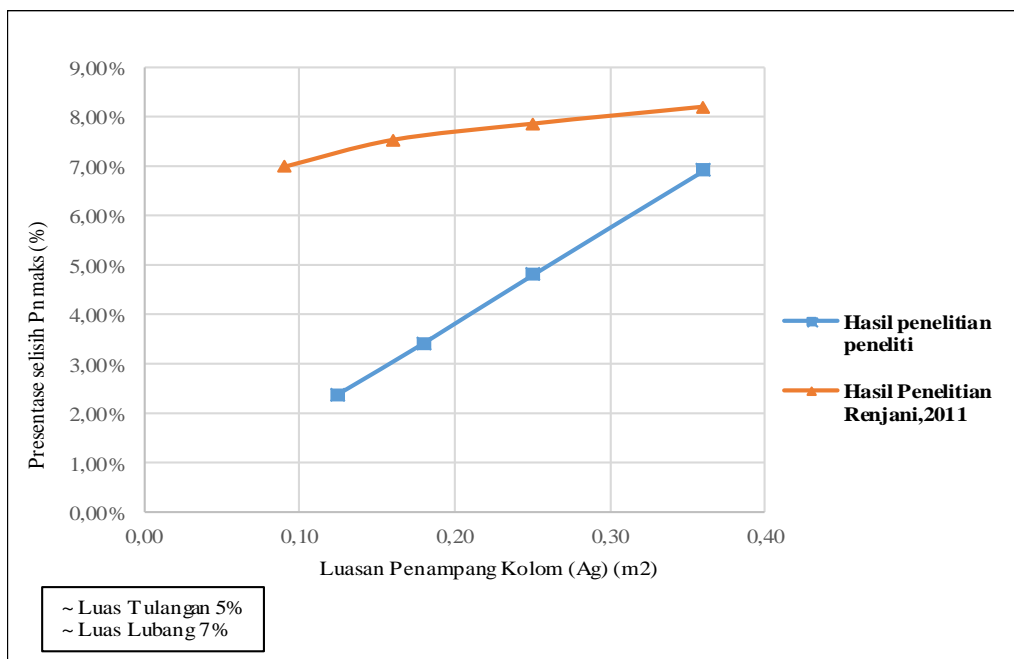

b. Mutu beton $27,5 \mathrm{MPa}$

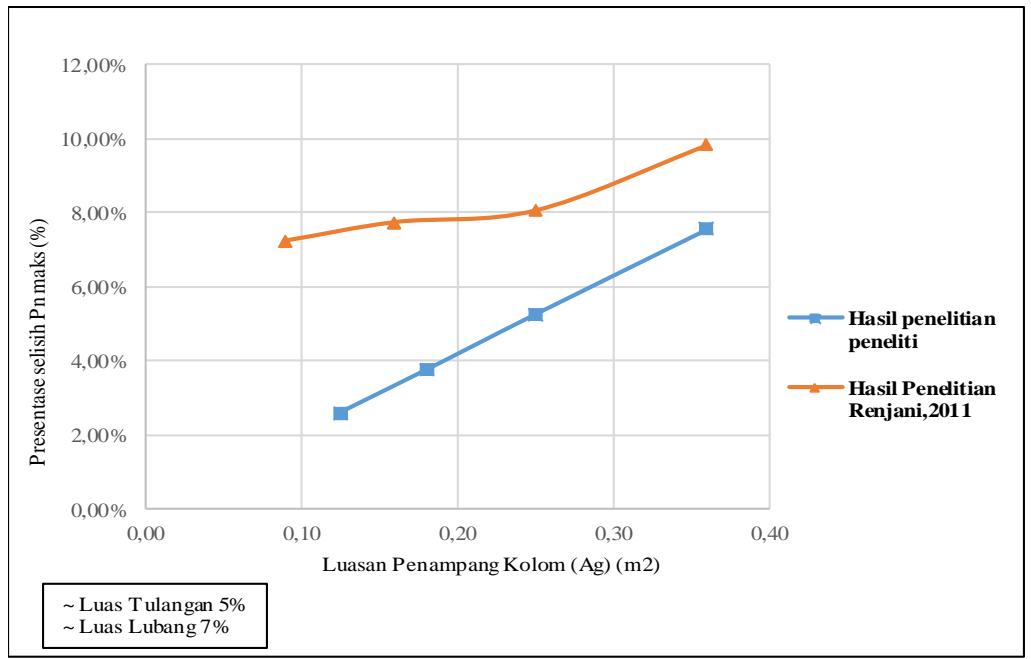

c. Mutu beton $30 \mathrm{MPa}$

Gambar 4. Grafik Perbandingan Presentase Selisih Pn Maksimum dengan Luas Tulangan 5\%, Luas Lubang $7 \%$ dan Luas Penampang Kolom $\left(\mathrm{A}_{\mathrm{g}}\right)$ 


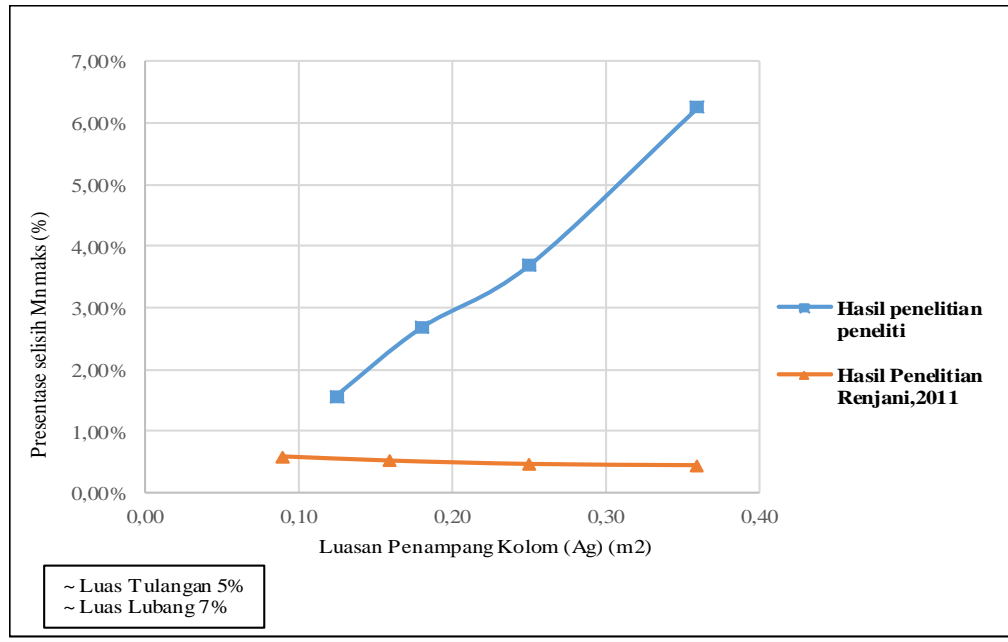

a. Mutu beton $25 \mathrm{MPa}$

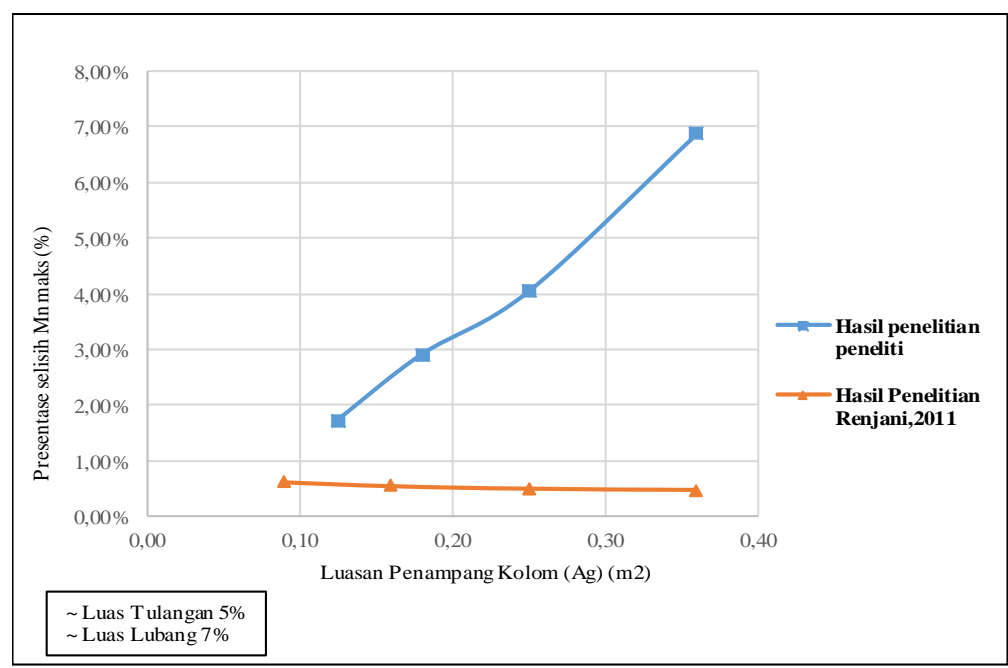

b. Mutu beton $27,5 \mathrm{MPa}$

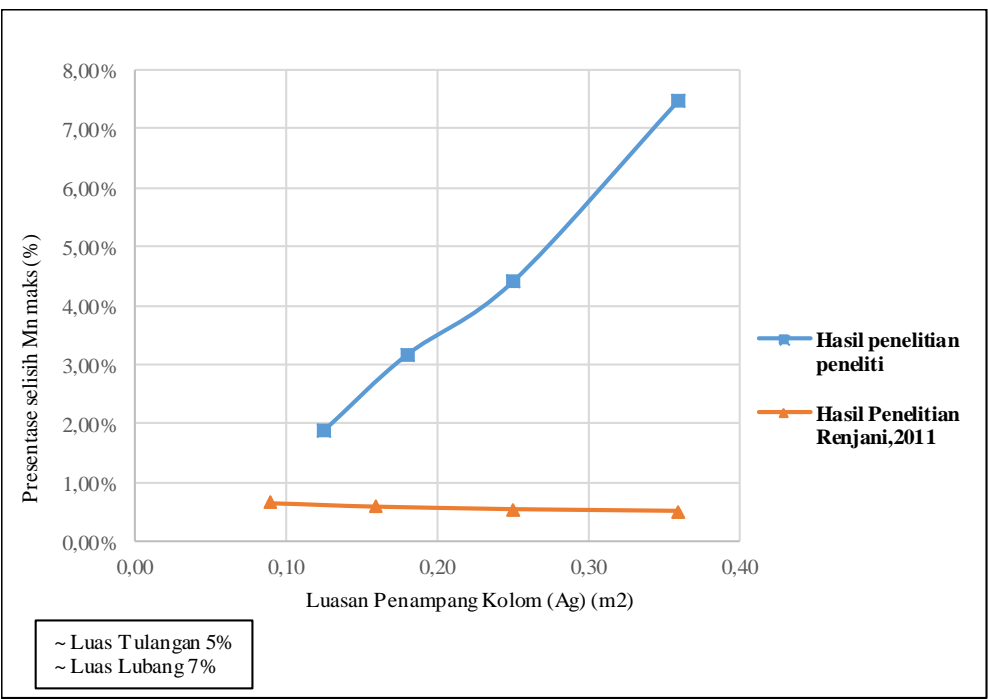

c. Mutu beton $30 \mathrm{MPa}$

Gambar 3 . Grafik Perbandingan Presentase Selisih Pn Maksimum dengan Luas Tulangan 5\%, Luas Lubang 7\% dan Luas Penampang Kolom $\left(\mathrm{A}_{\mathrm{g}}\right)$ 
Gambar 5 a, b dan c mengalami trend yang sama yaitu semakin besar bertambahnya luas penampang kolom $\left(\mathrm{A}_{\mathrm{g}}\right)$ semakin besar juga nilai persentase selisih Pn. Trend tersebut terjadi pada kedua hasil penelitian meskipun nilai persentase selisih Pn berbeda dimana hasil penelitian peneliti lebih kecil dibandingkan hasil penelitian Renjani (2011). Penambahan mutu beton (f'c) pada kedua hasil penelitian menyebabkan kenaikan persentase selisih Pn pada setiap luasan penampang kolom $\left(\mathrm{A}_{\mathrm{g}}\right)$. Gambar $6 \mathrm{a}$, $\mathrm{b}$ dan $\mathrm{c}$ mengalami trend yang berbeda diantara kedua penelitian. Trend tersebut terjadi karena penelitian peneliti mengalami kenaikan nilai persentase selisih $\mathrm{Mn}$ sedangkan penelitian Renjani (2011) mengalami penurunan seiring bertambahnya luasan penampang kolom $\left(\mathrm{A}_{\mathrm{g}}\right)$. Penambahan mutu beton (f'c) pada penelitian peneliti menyebabkan kenaikan persentase selisih Mn berbanding terbalik dengan penelitian Renjani (2011) yang mengalami penurunan pada setiap luasan penampang kolom $\left(\mathrm{A}_{\mathrm{g}}\right)$.

\section{KESIMPULAN}

Kesimpulan yang dapat disampaikan penulis dari penelitian ini adalah:

1. Semakin besar luas lubang maka persentase selisih Pn dan Mn kolom persegi panjang berlubang terhadap kolom tidak berlubang semakin besar.

2. Semakin besar rasio tulangan maka persentase selisih Pn dan Mn kolom persegi panjang untuk setiap luasan lubang semakin kecil.

3. Semakin besar mutu beton (f'c) maka semakin besar persentase selisih Pn dan Mn kolom persegi panjang untuk setiap luas lubang.

4. Semakin besar selisih antara lebar dan panjang kolom persegi panjang maka semakin besar pula persentase selisih Pn dan Mn pada setiap luasan lubang hal ini mengakibatkan penurunan kekuatan dari kolom tersebut.
5. Persentase selisih Pn maksimal sebesar $16,97 \%$ dengan eksentrisitas terhadap $\mathrm{d}$ sebesar $17,37 \%$ terjadi pada luas lubang $7 \%$, luas tulangan $3 \%$, mutu beton 30 MPa, dan dimensi kolom 450 x 1800 $\mathrm{mm}$.

6. Persentase selisih Mn maksimal sebesar $24,60 \%$ dengan eksentrisitas terhadap $d$ sebesar $68,71 \%$ terjadi pada luas lubang $7 \%$, luas tulangan $3 \%$, mutu beton 30 MPa, dan dimensi kolom 450 x 1800 $\mathrm{mm}$.

7. Luas lubang pada penampang kolom persegi panjang sebesar 7\% masih dapat digunakan dengan ketentuan untuk lebar kolom diatas $400 \mathrm{~mm}$ tidak dianjurkan merencanakan panjang kolom 200\%-300\% kali lebar kolomnya.

8. Ketentuan lainya dalam merencanakan kolom persegi panjang dengan luas lubang diatas $7 \%$ adalah dengan memperhatikan letak lubang harus benar-benar sentris di tengah penampang kolom.

9. Perbandingan hasil penelitian peneliti dengan penelitian sebelumnya tidak begitu berbeda jauh meskipun dibandingkan berdasarkan luasan penampang kolom $\left(\mathrm{A}_{\mathrm{g}}\right)$ antara kolom persegi panjang dengan kolom persegi.

\section{DAFTAR PUSTAKA}

Asroni, A., 2010, Kolom, Fondasi \& Balok T Beton Bertulang, Yogyakarta: Graha Ilmu.

Badan Standardisasi Nasional (BSN), 2013, Persyaratan Beton Struktural untuk Bangunan Gedung (SNI-2847-2013).

Inasari, Edy., 2014, Penelitian Dan Metode Ilmiah,

https://inasari894.wordpress.com/2014/0 4/06/penelitian-dan-metode-ilmiah/, 12 November 2017, 20.16 WIB.

Karsidi, R., 2007, Sosiologi Pendidikan, Surakarta: UNS Pres 
Nawy, E. G., 1998, Beton Bertulang Suatu Pendekatan Dasar, Bandung: Refika Aditama.

Park, R. And Pauly, T., 1974, Reinforced Concrete Structures, Departement Of Civil Engineering, University Of Canterbury, Cristchurch, New Zealand.

Renaningsih, 2006, Analisis Penampang Kolom Beton Bertulang Persegi Berlubang Menggunakan PCA-COL, Jurnal Ilmiah Teknik Sipil.
Renjani, M. S., 2011, Analisis Penampang Kolom Beton Bertulang Persegi Berlubang, Bengkulu: Universitas Bengkulu.

Sudarsana, 2010, Analisis Pengaruh Konfigurasi Tulangan terhadap Kekuatan dan Daktailitas Kolom Beton Bertulang, Jurnal Ilmiah Teknik Sipil.

Wahyudi, L. dan Rahim, Syahril A., 1997. Struktur Beton Bertulang, Jakarta: PT Gramedia Pustaka Utama. 
ISSN 2086-9045

Email:Inersia@unib.ac.id 